\section{DIABETES AND PREGNANCY}

BY

J. C. PEASE, D.M., M.R.C.P.

Senior Registrar, Radcliffe Infirmary, Oxford

V. SMALLPEICE, M.D., M.R.C.P.

Paediatrician, Radcliffe Infirmary, Oxford

AND

\section{G. GORDON LENNON, Ch.M., M.R.C.O.G. M.M.S.A.}

Formerly First Assistant, Nuffield Department of Obstetrics and Gynaecology, Oxford; Professor of Obstetrics and Gynaecology, University of Bristol

Since the beginning of 1947 , at the Radcliffe Infirmary, Oxford, 21 diabetic patients have had 25 pregnancies extending beyond the 28 th week. No mother died, and 23 babies are living. The remaining two were stillborn.

The British Medical Journal (1949) stated: "It seems probable that termination of pregnancy has failed to reduce the overall foetal mortality because, while many late intrauterine deaths are avoided, it has increased the neonatal death rate due to prematurity (in spite of the large size of the infants). To be of real value, oestrogens - or any other therapeutic agents-must be able to avert late intrauterine death and so enable full-term birth to occur with its much reduced likelihood of neonatal death."

The numbers in the Radcliffe Infirmary series are small, but few clinics have large numbers for analysis. We consider the present report justified if only to show that early induction of labour and prematurity need not increase the neonatal death rate. This point is brought out in Table I.

TABLE I.-Babies Born of Diabetic Mothers

\begin{tabular}{|c|c|c|c|c|c|c|}
\hline \multirow{2}{*}{ Period } & \multirow{2}{*}{ Baby } & \multirow{2}{*}{$\begin{array}{c}\text { 36th Week } \\
\text { or } \\
\text { Before }\end{array}$} & \multirow{2}{*}{$\begin{array}{c}37 \text { th Week } \\
\text { or } \\
\text { After }\end{array}$} & \multicolumn{2}{|c|}{ Total } & \multirow{2}{*}{$\begin{array}{c}\text { Foetal } \\
\text { Loss }\end{array}$} \\
\hline & & & & Alive & Dead & \\
\hline $1930-42$ & $\begin{array}{l}\text { Alive } \ldots \\
\text { Stillbirth } \\
\text { Neonatal death }\end{array}$ & $\begin{array}{l}1 \\
2 \\
0\end{array}$ & $\begin{array}{l}5 \\
7 \\
0\end{array}$ & 6 & 9 & $60 \%$ \\
\hline 1943-6 & $\begin{array}{l}\text { Alive } . . \\
\text { Stillbirth } \\
\text { Neonatal death }\end{array}$ & $\begin{array}{l}3 \\
4 \\
2\end{array}$ & $\begin{array}{l}6 \\
3 \\
0\end{array}$ & 9 & 9 & $50 \%$ \\
\hline $1947-5.0$ & $\begin{array}{l}\text { Alive } . . \\
\text { Stillbirth } \\
\text { Neonatal death }\end{array}$ & $\begin{array}{r}18 \\
1 \\
0\end{array}$ & $\begin{array}{l}5 \\
1 \\
0\end{array}$ & 23 & 2 & $8 \%$ \\
\hline
\end{tabular}

These results may be compared with those of Reis, DeCosta, and Allweiss (1950), Peel and Oakley (1950), and White (1949). The figures are given in Table II.

TABLE II.-Results in Other Series

\begin{tabular}{|c|c|c|c|c|c|c|}
\hline Series & Period & Alive & $\begin{array}{l}\text { Still- } \\
\text { births }\end{array}$ & $\begin{array}{c}\text { Neonatal } \\
\text { Deaths }\end{array}$ & Total & $\begin{array}{c}\text { Foetal } \\
\text { Loss }\end{array}$ \\
\hline $\begin{array}{l}\text { Reis et al. } \\
\text { Peel and Oakley } \\
\text { White }\end{array}$ & $\begin{array}{l}1935-50 \\
1942-9 \\
1934-49\end{array}$ & $\begin{array}{r}51 \\
106 \\
361\end{array}$ & $\begin{array}{r}6 \\
16 \\
34\end{array}$ & $\begin{array}{r}2 \\
20 \\
44\end{array}$ & $\begin{array}{r}59 \\
142 \\
439\end{array}$ & $\begin{array}{l}13.5 \% \\
24.9 \% \\
18 \%\end{array}$ \\
\hline
\end{tabular}

The foetal loss rates are high when compared with the figure of $5.2 \%$ (excluding abortions and miscarriages) given by Gilbert and Dunlop (1949) as representing the foetal loss rate in 3,276 pregnancies in non-diabetic patients attending the Ayr County Maternity Service.

\section{Present Investigation}

During the past four years the management of diabetic pregnancies in Oxford has been under the care of a team consisting of physician, obstetrician, and paediatrician. Table III gives the facts relating to the diabetic and obstetrical histories of 25 consecutive pregnancies at the Radcliffe Infirmary during that period.

TABLE III.-The Obstetrical History of the 25 Consecutive Diabetic Pregnancies

\begin{tabular}{|c|c|c|c|c|c|c|c|c|c|}
\hline Year & 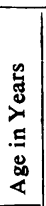 & 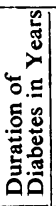 & 密 & $\left|\begin{array}{ll}4 & 2 \\
0 & 0 \\
8 & \vdots \\
3 & 0\end{array}\right|$ & 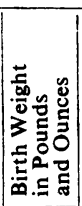 & $\sum_{\substack{0 \\
0}}^{\stackrel{0}{0}}$ & 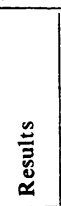 & 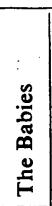 & Comment \\
\hline 1947 & $\begin{array}{l}28 \\
27 \\
43 \\
25\end{array}$ & $\begin{array}{r}11 \\
1 \\
3\end{array}$ & $\begin{array}{l}0 \\
0 \\
5 \\
1\end{array}$ & $\begin{array}{l}37 \\
37 \\
33 \\
37\end{array}$ & $\begin{array}{l}8 \cdot 9 \\
7 \cdot 0 \\
7 \cdot 1 \\
8 \cdot 1\end{array}$ & $\begin{array}{l}\dot{M} S \\
\text { Mp } \\
\text { MS } \\
\text { MS }\end{array}$ & $\begin{array}{l}\text { Sb } \\
\text { A } \\
\text { A } \\
\text { A }\end{array}$ & & $\begin{array}{l}\text { Moderate control only } \\
\text { Oedema } \\
\text { Toxaemia, diet only, } \\
\text { oedematous baby }\end{array}$ \\
\hline 1948 & $\begin{array}{l}38 \\
32 \\
27 \\
35 \\
29 \\
24\end{array}$ & $\begin{array}{l}5 \\
2 \\
4 \\
0 \\
1 \\
4\end{array}$ & $\begin{array}{l}2 \\
3 \\
1 \\
5 \\
1 \\
0\end{array}$ & $\begin{array}{l}36 \\
34 \\
36 \\
36 \\
35 \\
34 \\
\\
\\
34 \\
36\end{array}$ & $\begin{array}{l}8 \cdot 7 \\
7 \cdot 6 \\
6 \cdot 6 \\
7 \cdot 7 \\
8 \cdot 1 \\
5 \cdot 3 \\
\\
6 \cdot 11 \\
8 \cdot 7\end{array}$ & $\begin{array}{l}\text { M } \\
\mathbf{C} \\
\mathbf{C} \\
\mathrm{MS} \\
\mathrm{C} \\
\mathrm{S} \\
\mathrm{MS} \\
\mathrm{C}\end{array}$ & $\begin{array}{l}\text { A } \\
\text { A } \\
\text { A } \\
\text { A } \\
\text { A } \\
\text { MF } \\
\text { A } \\
\text { A }\end{array}$ & $\begin{array}{l}\mathbf{L} \\
\mathbf{L}\end{array}$ & $\begin{array}{l}\text { Hydramnios } \\
\text { Hydramnios } \\
\text { Hypertension, hydram- } \\
\text { nios } \\
\text { Hypertension, hydram- } \\
\text { nios, breech, accidental } \\
\text { haemorrhage } \\
\text { Hydramnios }\end{array}$ \\
\hline 1949 & $\begin{array}{l}25 \\
20 \\
28 \\
27 \\
25\end{array}$ & $\begin{array}{r}4 \\
0 \\
9 \\
16 \\
6\end{array}$ & $\begin{array}{l}0 \\
0 \\
1 \\
1 \\
1\end{array}$ & $\begin{array}{l}36 \\
37 \\
35 \\
36 \\
36\end{array}$ & $\begin{array}{r}7 \cdot 8 \\
10 \cdot 1 \\
6 \cdot 5 \\
5 \cdot 9 \\
6 \cdot 9\end{array}$ & $\begin{array}{l}\text { Sp } \\
\text { Sp } \\
\text { MS } \\
\text { C } \\
\text { C }\end{array}$ & $\begin{array}{l}\mathbf{A} \\
\mathbf{A} \\
\mathbf{A} \\
\mathbf{A} \\
\mathbf{A}\end{array}$ & $\begin{array}{l}\mathbf{L} \\
\mathbf{L} \\
\mathbf{L} \\
\mathbf{C} \mathbf{v} \\
\mathbf{L}\end{array}$ & $\begin{array}{l}\text { Oedema } \\
\text { Toxaemia, post-partum } \\
\text { eclampsia } \\
\text { Hydramnios } \\
\text { Toxaemia } \\
\text { Hypertension }\end{array}$ \\
\hline 1950 & $\begin{array}{l}28 \\
29 \\
28 \\
32 \\
24 \\
37 \\
30 \\
41\end{array}$ & $\begin{array}{r}7 \\
6 \\
2 \\
3 \\
11 \\
2 \\
4 \\
0\end{array}$ & $\begin{array}{l}1 \\
2 \\
1 \\
2 \\
0 \\
6 \\
1 \\
1\end{array}$ & $\begin{array}{l}34 \\
35 \\
35 \\
36 \\
36 \\
36 \\
36 \\
37\end{array}$ & $\begin{array}{l}6 \cdot 11 \\
7 \cdot 4 \\
6 \cdot 10 \\
7 \cdot 15 \\
8 \cdot 11 \\
7 \cdot 3 \\
6 \cdot 10 \\
8 \cdot 4\end{array}$ & $\begin{array}{l}\text { Sp } \\
\text { C } \\
\text { MS } \\
\text { C } \\
\text { C } \\
\text { MS } \\
\text { MS } \\
\text { S }\end{array}$ & $\begin{array}{l}\mathbf{A} \\
\mathbf{A} \\
\mathbf{A} \\
\mathbf{A} \\
\mathbf{A} \\
\mathbf{A} \\
\mathbf{A} \\
\mathbf{A}\end{array}$ & $\begin{array}{l}\mathrm{L} \\
\mathrm{Cv}\end{array}$ & $\begin{array}{l}\stackrel{-}{=} \\
\overline{-} \\
\text { Cyanotic baby } \\
\text { Toxaemia } \\
\text { Toxaemia, hydramnios, } \\
\text { diet only }\end{array}$ \\
\hline
\end{tabular}

$\mathrm{A}=$ Alive and well. $\mathrm{C}=$ Caesarean section (lower segment). $\mathrm{Cv}=\mathrm{Con}-$ vulsions. $\mathbf{L}=\mathbf{M a r k e d}$ lethargy. $\mathbf{M}=$ Medical induction. $\mathbf{M F}=\mathbf{M a c e r}$ $\mathrm{Sp}=$ Spontaneous delivery. $\mathrm{Sb}=$ Stillbirth.

\section{The Antenatal Period}

During the first six months of pregnancy the patient attends the diabetic and antenatal clinics once a month and for the remainder of the pregnancy attendances are fortnightly or weekly. Most patients are admitted to the medical wards during the middle trimester for assessment of their diabetic and physical state, and to the maternity home during the 35 th week in the absence of other indications-for example, toxaemia which may have necessitated earlier admission. Twelve of the mothers in our series developed diabetes between the ages of 21 and 30, eight were younger and five were older. Seventeen of the patients had had diabetes mellitus for five years or less, four between six and nine years, three between ten and fifteen years, and one for sixteen years. One patient was found to have diabetes a few days before delivery; the remainder, with two exceptions, had attended the diabetic clinic regularly. None of these patients had hypertension, albuminuria, or retinitis on their discharge from the maternity home. Eight were nulliparae, ten had had one child, and seven had had two or more children.

The renal threshold was found to be low in 15 cases, in three it was normal, and in the remainder no estimation had been made. Four of the patients were excreting in the urine daily more than $80 \mathrm{~g}$. of reducing substances as tested by Benedict's solution. Two patients 
were stabilized on diet alone; three required less than 20 units of insulin and 14 more than 60 units each day. Twenty-one patients had their diets increased, 17 their insulin increased, three their insulin reduced, and the remainder required no change. The management of a mother's diabetes when she is admitted to the maternity home is kept as simple as possible. The registrar of the diabetic clinic and the dietitian see the patient soon after admission. Soluble insulin only is used, and a patient on a high dosage of insulin is given the same dose in three or four injections a day. The dietitian makes the necessary adjustment to the diet. She arranges for a fluid diet, containing the calorie equivalent of the carbohydrate normally taken, if the patient is unable to take the full diet during or after delivery. If a caesarean operation is to be done the time is fixed after the physician and obstetrician have consulted.

\section{Hormone Therapy}

Hormone treatment was not used, because biological assay could not easily be done and because uncontrolled use of oestrogens was thought undesirable.

White (1949) attributes the high foetal survival figure in her series to hormone therapy, but at present no adequate explanation of the rationale for this treatment has been given. Other factors, such as termination of pregnancy at the 35 th or 36 th week and the increasing experience and knowledge of the team dealing with these cases, may have played an important part in the good results achieved. In a much smaller series of cases Reis et al. (1950) have had, without the aid of endocrine therapy, a foetal and neonatal death rate of $13.5 \%$.

It is premature to make any dogmatic statement about the part that hormone therapy plays in the management of pregnancies in diabetic patients. The controversy which this form of treatment has raised may inspire the publication of other series of cases treated with and without the uses of hormones. Any comments on White's results must take into account: (1) that she has supervised 439 diabetic pregnancies, in which $58 \%$ of the mothers had developed diabetes before the age of 20 and $50 \%$ had had diabetes for more than 10 years; and (2) that the foetal survival rate was $95 \%$ (47 cases) where there was no sex hormone imbalance, $58 \%$ (89 cases) when the imbalance was uncorrected, and 89\% (297 cases) when corrected by oestrogen therapy.

\section{Complications of Pregnancy"}

Toxaemia.-Eight patients developed hypertension (blood pressure of more than 130/90), eight oedema, one albuminuria, and one post-partum eclampsia. Five had two or more of the factors which constitute toxaemia of pregnancy, an incidence of $19 \%$.

Hydramnios. - Six patients had hydramnios, an incidence of $23 \%$, which is higher than usual. There were no gross foetal abnórmalities.

Obstetrical Problems.-Table IV shows the duration of pregnancy, the mode of delivery, and the parity of the mothers in the 25 consecutive pregnancies.

\begin{tabular}{|c|c|c|c|c|c|}
\hline & $\begin{array}{l}\text { Week of } \\
\text { Delivery }\end{array}$ & & Spontaneous & $\begin{array}{c}\text { Medical or } \\
\text { Surgical Induction }\end{array}$ & $\begin{array}{c}\text { Caesarean } \\
\text { Section }\end{array}$ \\
\hline $\begin{array}{l}\text { 33rd } \\
34 \text { th } \\
35 \text { th } \\
36 \text { th } \\
37 \text { th }\end{array}$ & $\begin{array}{l}\ldots \\
\ldots \\
\ldots \\
\ldots\end{array}$ & $\begin{array}{l}\ldots \\
\because \\
\cdots \\
\cdots\end{array}$ & $\begin{array}{l}1 \mathrm{M} \\
3 \mathrm{P}\end{array}$ & $\begin{array}{l}\cdot 1 \mathrm{M} \\
2 \mathrm{P} \\
2 \mathrm{M} \\
4 \mathrm{M} \\
2 \mathrm{M}, 1 \mathrm{P}^{*}\end{array}$ & $\begin{array}{l}1 \mathrm{M} \\
3 \mathrm{M} \\
3 \mathrm{M}, 2 \mathrm{P}\end{array}$ \\
\hline
\end{tabular}

The good neonatal results achieved have now confirmed one of us (G. G. L.) in the belief that termination in the uncomplicated case should be undertaken just before the $36 \mathrm{th}$ week of pregnancy, and that delivery should be completed by the end of the 36th week. It is better to get out of the uterus a live child for which something can be done than one already dead. The only problem is the method of termination. For both primigravida and multigravida caesarean section is being more readily employed. Both of the babies born dead in the series followed surgical induction in primigravidae by membrane rupture or puncture, in one case at the 34th week and in the other at the 37th week of pregnancy. Certainly the finding of an " unripe" cervix will necessitate a caesarean section.

In the multipara, surgical induction by liquor-loss is more likely to be followed by the onset of labour, but undue delay should cause reassessment of the case and resort in many instances to caesarean section.

\section{The Newborn Infant}

Twenty-three babies were born alive and all survived, though many proved slow and difficult to establish. In 11 there was a loss of weight of $12 \mathrm{oz}$. (340 g.) or more within the first nine days. Convulsions yere recorded in two infants, both apparently due to cerebral birth injury. None was discharged under 2 weeks of age and seven were kept in hospital three weeks or longer. At birth the baby was invariably large and heavy in relation to the period of gestation, whilst its behaviour resembled that of an infant of considerably greater prematurity. Lethargy was the outstanding feature, and cyanotic attacks occurred.

The infants of these diabetic mothers were treated on the same general plan as the smaller premature babies, except that we did not withhold all feeds and fluids from them for 48 hours. Great care was taken to clear the airways at birth and to prevent cooling ; oxygen was not administered as a routine, but the more premature and less vigorous infants were admitted to the premature nursery immediately and, if necessary, placed in an oxygen tent. The infants were nursed with the minimum of disturbance, being turned from side to side but neither washed nor dressed until they showed signs of increasing vigour. There may be a delay of several days before this stage is reached. In this connexion it is of interest that Reis et al. (1950) take the opposite view and advise " frequent and continued mechanical stimulation to overcome lethargy," whilst others prescribe thyroid for the same purpose.

There is as yet no satisfactory answer to the question why these babies are so difficult to establish. Congenital malformations and poor resistance to infection account for a very small proportion of neonatal deaths. At first sight hypoglycaemia, either relative or absolute, would appear to be the most likely source of trouble. The normal newborn infant shows both low bloodsugar levels and great variability in the first days of life (Norval et al., 1949). Premature infants usually reach even lower levels.

Smith (1946) considers that a "particular neonatal tolerance to low blood sugar may confer a relative resistance to hypoglycaemic stimuli just as it does to anoxia." White (1946) gives neither fluids nor feeds (glucose feeds were abandoned in 1940) for the first days of life, treating the infants in this respect as the premature babies of non-diabetic mothers are treated at the 
Radcliffe Infirmary. Reis et al. (1950), whose good results have already been mentioned, consider that the blood sugar in the infant of a diabetic mother tends to fall more rapidly, to reach lower levels, and to return to normal more slowly than in the normal infant, a marked fall in the first hour being characteristic. They advocate giving $50 \%$ glucose solution by mouth from the first half-hour of life, but changing to $5 \%$ glucose solution after two hours. Peel and Oakley (1950) have studied a few cases and confirm this very rapid fall in blood-sugar levels immediately after birth. As the results at the Radcliffe Infirmary are satisfactory we are continuing to give $5 \%$ solution in $\frac{1}{2}-$ to $1-\mathrm{oz}$. (14- to 28-ml.) feeds every two to four hours during the first one or two days.

We have had no experience of the effect of repeated gastric aspirations for infants delivered by caesarean section as advocated by Gellis, White, and Pfeffer (1949) with a view to minimizing the risk of regurgitation and inhalation of vomit.

Lactation may be difficult to establish in the diabetic woman, and this, together with the lethargy and poor condition of the infant, leads to failure in breast-feeding in a proportion of cases. As a rule nothing is to be gained by putting the infant to the breast early; the mother expresses the milk until the stage of engorgement is over, by which time the infant is likely to be more vigorous and able to suck from the breast. Ten mothers in the present series breast-fed their babies satisfactorily.

If the close co-operation of the obstetrician and the physician can reduce stillbirths and intrauterine deaths, allowing the well-controlled diabetic mother to be delivered of a live baby, then the infant should stand a good chance of survival even when it is born at the 36th week. After birth the skill of the nursing staff is the most important factor in reducing neonatal deaths.

\section{Summary and Conclusions}

A series of 25 consecutive diabetic pregnancies beyond the 28th week (1947 to 1950 ) is presented. No mother died and 23 babies are living. Although this series is small it shows that good results have been obtained by adopting the principles of (1) working as a team with a definite policy ; (2) careful diabetic control ; (3) induction of labour not later than the 36th week of pregnancy ; and (4) careful neonatal control but without overtreatment of the baby.

We acknowledge our thanks to Dr. A. M. Cooke, head of the Radcliffe Infirmary Diabetic Clinic, to Dr. D. C. Lewin (registrar, Diabetic Clinic, 1947-8), and to Professor J. Chassar Moir and Mr. J. Stallworthy for allowing us to publish details of their patients. We thank Sister Ware, who has been in charge of the nurseries in the maternity department for the last four years, for her invaluable help.

\section{REFERENCES}

British Medical Journal (1949). 1, 62.

Gellis, S. S., White, P., and Pfeffer, W. (1949). New Engl. J. Med., 240, 533.

Gilbert, J. A. L., and Dunlop, D. M. (1949). British Medical Journal, 1, 48.

Norval, M. A., Kennedy, R. L. J., and Berkson, J. (1949). J. Pediat., 34, 342.

Peel, J., and Oakley, W. (1950). Trans. 12th Brit. Cong. Obstet. Gynaec., p. 161.

Reis, R. A., DeCosta, E. J., and Allweiss, M. D. (1950). Amer. J. Obstet. Gynec., 60, 1023

Smith, C. A. (1946). Physiology of the Newborn Infant. Thomas, Illinois.

White, P. (1946). In Joslin's Treatment of Diabetes Mellitus, 8th ed. Kimpton, London. (1949). Amer. J. Med., 7, 609.

\section{LYMPHOCYTIC CHORIOMENINGITIS ASSOCIATED HUMAN AND MOUSE INFECTIONS}

BY

\author{
E. H. R. SMITHARD, M.B.E., M.D., D.P.H. \\ M.O.H., Metropolitan Borough of Lewisham
}

AND

A. D. MACRAE, M.D.

Virus Reference Laboratory, Central Public Health Laboratory, Colindale, N.W.9

Lymphocytic choriomeningitis (L.C.M.) was first differentiated from other types of aseptic meningitis by Rivers and Scott (1935), the causative virus having been described by Armstrong and Lillie (1934). The main reservoir of infection occurs in the house mouse (Mus musculus), but laboratory experiments have suggested that bed bugs, mosquitoes, lice, and trichinella larvae may be implicated in the spread of the disease (see van Rooyen and Rhodes, 1948).

In investigations of houses in areas in which human infection occurred, Armstrong (1940) found that approximately $40 \%$ harboured infected mice, and about $50 \%$ of the mice trapped in such premises were found to be carriers of active virus, which they may excrete in saliva and nasal secretions, urine, and faeces. Transmission to man probably takes place via contaminated food or by the inhalation of dust infected from mouse excreta, with possibly occasional arthropod transmission. It has not been proved that man-to-man transmissions may occur. Mice infected naturally may carry the virus throughout life and the female may transmit it to her offspring.

Wooley et al. (1937) reported that up to $12 \%$ of samples of serum from persons not suffering from the disease possessed neutralizing antibodies against L.C.M. virus, but this has not been confirmed in recent years in U.S.A. or elsewhere. MacCallum $(1949,1950)$ has found that only 3 to $5 \%$ of two series of cases of lymphocytic meningitis investigated in England in 1947-9 had had a recent infection with this virus.

Final diagnosis depends on laboratory methods. The virus has been isolated from blood, cerebrospinal fluid, and nasopharyngeal secretions during the febrile period by intraperitoneal inoculation into guinea-pigs or intracerebral inoculation into mice. Complement-fixing antibodies develop in the serum three to four weeks, and neutralizing antibodies usually six to eight weeks, after the onset of illness.

After exposure to the virus an incubation period of 5-10 days may be followed by an influenza-like attack of 7-20 days' duration. Recovery may ensue or, after some days' remission, meningeal symptoms may appear. These persist for 7-30 days, gradually recede, and are followed by recovery. Few fatal cases of proved infection have been reported (Smadel et al., 1942). Sometimes the attack is initiated by meningeal symptoms and in severe cases there may be somnolence, disturbed deep reflexes, and paralysis. The cerebrospinal fluid is sterile bacteriologically, and cell counts range from a few hundred to 3,500 , mainly lymphocytes.

The differential diagnosis includes other forms of meningitis, encephalitis, and anterior poliomyelitis. 